\title{
DIFFERENTIAL SENSITIVITY OF MALE GERM CELLS TO MAINSTREAM AND SIDESTREAM TOBACCO SMOKE IN THE MOUSE
}

\author{
Aris Polyzos ${ }^{1}$, Thomas Ernst Schmid ${ }^{1,2}$, Belem Piña-Guzmán ${ }^{3}$, Betzabet Quintanilla-Vega ${ }^{3}$, \\ Francesco Marchetti ${ }^{1,4}$ \\ ${ }^{1}$ Life Sciences Division, Lawrence Berkeley National Laboratory, Berkeley, CA, USA; \\ ${ }^{3}$ Toxicology Section, CINVESTAV-IPN, Mexico City, Mexico \\ ${ }^{2}$ Present address: Klinikum rechts der Isar, Technische Universitaet Muenchen, Munich, \\ Germany
}

${ }^{4}$ Corresponding author:

Dr. Francesco Marchetti

Life Sciences Division

Lawrence Berkeley National Laboratory

1 Cyclotron Road, MS 74R0157

Berkeley CA 94720

(510) 4867352

(510) 4866691

fmarchetti@lbl.gov 


\begin{abstract}
Cigarette smoking in men has been associated with increased chromosomal abnormalities in sperm and with increased risks for spontaneous abortions, birth defects and neonatal death. Little is known, however, about the reproductive consequences of paternal exposure to secondhand smoke. We used a mouse model to investigate the effects of paternal exposure to sidestream (SS) smoke, the main constituent of second-hand smoke, on the genetic integrity and function of sperm, and to determine whether male germ cells were equally sensitive to mainstream (MS) and SS smoke. A series of sperm DNA quality and reproductive endpoints were investigated after exposing male mice for two weeks to MS or SS smoke. Our results indicated that: (i) only SS smoke significantly affected sperm motility; (ii) only MS smoke induced DNA strand breaks in sperm; (iii) both MS and SS smoke increased sperm chromatin structure abnormalities; and (iv) MS smoke affected both fertilization and the rate of early embryonic development, while SS smoke affected fertilization only. These results show that MS and SS smoke have differential effects on the genetic integrity and function of sperm and provide further evidence that male exposure to second-hand smoke, as well as direct cigarette smoke, may diminish a couple's chance for a successful pregnancy and the birth of a healthy baby.
\end{abstract}

Key words: Comet, SCSA, CASA, fertilization, 4-cell embryo 


\section{INTRODUCTION}

About 35\% of men in the United States smoke cigarettes (The Practice Committee of the American Society for Reproductive Medicine, 2004) and there is substantial epidemiological evidence associating paternal smoking with increased risks for spontaneous abortions (Venners et al., 2004), birth defects and childhood cancer (Ji et al., 1997; Chang et al., 2006). Prior studies have shown that cigarette smokers have increased levels of oxidative damage (Fraga et al., 1996; Shen et al., 1997), DNA strand breaks (Potts et al., 1999), DNA adducts (Horak et al., 2003), and chromosomal abnormalities (Robbins et al., 1997; Rubes et al., 1998) in their sperm. In addition, diminished semen volume, sperm concentration, total sperm count and motile spermatozoa have been associated with the number of cigarettes smoked daily (Ramlau-Hansen et al., 2007). Also, the time to pregnancy increases among couples where the male partner smokes more than 15 cigarettes/day (Hughes and Brennan, 1996; Ford et al., 2000), although there is no apparent association with loss of fecundity. Rodent studies have corroborated these findings. Exposing male mice to mainstream (MS) tobacco smoke, the main smoke inhaled by active smokers, induced genetic mutations in sperm (Yauk et al., 2007), reduced sperm fertilizing capacity (Kapawa et al., 2004), and decreased embryonic implantation rates (Kapawa et al., 2004).

It is estimated that up to $\sim 60 \%$ of nonsmokers are exposed to second-hand cigarette smoke (U.S. Department of Health and Human Services, 2006; Shields, 2007). Evidence is rapidly accumulating that exposure to second-hand smoke is deleterious to human health and that there is no risk free level of exposure (California Environmental Protection Agency, 2005; U.S. Department of Health and Human Services, 2006). Significant progress has been made in reducing smoking in public spaces, however, exposure to second-hand smoke remains a public health concern and additional research is required to characterize the health effects of passive smoking. In addition, there is a significant effort from the tobacco industry in discrediting research on the harmful effects of second-hand smoking and avoiding stricter regulation to tobacco smoking in public places (Barnoya and Glantz, 2005a; Sebrié et al., 2005). Second-hand smoke is composed primarily ( $\sim 90 \%)$ by the sidestream (SS) smoke emitted from the smoldering end of the cigarette and $\sim 10 \%$ of exhaled MS smoke (Committee on Passive Smoking, 1986). SS smoke is a mixture of over 4000 chemicals, including more than 50 carcinogens and 200 toxicants (U.S. Department of Health and Human Services, 2006). Although there are few 
qualitative differences between MS and SS smoke (Fowles and Dybing, 2003), some toxicants, including carcinogens, are significantly elevated in SS smoke (Mohtashamipur et al., 1990; Fowles and Dybing, 2003; California Environmental Protection Agency, 2005). This suggests that passive smoking may produce effects that differ from those induced by active smoking.

Very little is known about the germ cell effects and reproductive consequences of exposure to second-hand smoke. In humans, maternal exposure to second-hand smoke during pregnancy has been associated with low birth weight, enhanced susceptibility to respiratory diseases and sudden infant dead syndrome in infants (Haglund and Cnattingius, 1990; KlonoffCohen et al., 1995; Taylor and Sanderson, 1995), reduced implantation rates after IVF (Neal et al., 2005), and increased risk of spontaneous abortions in adulthood (Meeker et al., 2007). Rodent pups born to mothers exposed to SS smoke during pregnancy have reduced growth (Rajini et al., 1994; Witschi et al., 1994; Nelson et al., 1999) and abnormal morphological changes, including increased apoptosis, in several tissues (Nelson et al., 1999). There are, however, very limited human or animal data on the germ cell and reproductive effects of paternal exposure to second-hand smoke. The paucity of information on the reproductive effects of paternal exposure to second hand smoke has so far prevented the determination of whether there is an association between second hand smoke and male reproductive dysfunction (California Environmental Protection Agency, 2005; U.S. Department of Health and Human Services, 2006).

The objectives of this study were to use a mouse model to investigate whether male exposure to MS or SS smoke affected the function and genetic integrity of sperm, fertilization and early embryonic development rates, and whether the effects differed between the two types of smoke. We targeted the last two weeks of spermatogenesis because they are characterized by: (i) a progressive reduction in the ability of male germ cells to carry out DNA repair (Marchetti and Wyrobek, 2008); (ii) an extensive remodeling of the sperm chromatin that results in the replacement of histones with protamines (Kimmins and Sassone-Corsi, 2005; Leduc et al., 2008); and (iii) the acquisition of motility and fertilizing capacity as sperm transverse the epididymis (Soler et al., 1994). We report that SS smoke exposure has deleterious effects on the male germline and that the effects differ from those induced by MS smoke. 


\section{MATERIALS AND METHODS}

\section{Animals}

B6C3F1/Crl mice 6-8 weeks of age at the beginning of the experiments were kept in a 12 $\mathrm{hr}$ light $/ 12 \mathrm{hr}$ dark photoperiod at ambient temperature $\left(21-23^{\circ} \mathrm{C}\right)$ and a relative humidity of 50 $\pm 5 \%$. Sterilized tap water and pelleted food were provided ad libitum. The use of animals in this study was approved by the LBNL Institutional Animal Care and Use Committee.

\section{Tobacco Smoke Exposures}

Male mice were exposed in inhalation chambers $(8.4 \mathrm{~L}$ chamber, 4 mice/chamber, 6 chambers/exposure) to tobacco smoke generated by a smoking machine ( $\mathrm{CH}$ Technologies, Westwood, NJ; Supplementary Figure 1A) using 2R4F research grade cigarettes (University of Kentucky, Lexington, KY). The smoking machine was set to a 2 sec puff every 15 seconds during which $45 \mathrm{~mL}$ of MS smoke was aspirated. MS smoke was diluted to a final concentration of $4 \%$ with clean air before delivery to the exposure chambers (Supplementary Figure 1B). For SS exposure (Supplementary Figure 1C), the SS smoke was collected using a bell jar at the same flow rate used for MS smoke (4.5 L/min). Male mice were exposed to either 3 or 16 cigarettes per day for 14 days, for a total of 4 experimental groups, plus controls: 3 MS, $16 \mathrm{MS}, 3 \mathrm{SS}$ and 16 SS (these codes refers to the number of daily cigarettes and type of smoke that each group was exposed to). The daily exposures were conducted in two sessions, one in the morning and one in the afternoon separated by $\sim 4 \mathrm{hr}$, during which half of the daily dose of cigarettes was administered. Males exposed to 3 or 16 cigarettes were in the inhalation chambers for $\sim 22$ $\mathrm{min} /$ day or $\sim 92 \mathrm{~min} /$ day total, respectively. During these daily sessions, the total suspended particulate (TSP) concentrations inside the cages averaged $30.2 \pm 5.5,74.5 \pm 18.9,4.8 \pm 2.2$ and $13.8 \pm 1.4 \mathrm{mg} / \mathrm{m}^{3}$ for $3 \mathrm{MS}, 16 \mathrm{MS}, 3 \mathrm{SS}$ and $16 \mathrm{SS}$, respectively. Mice were rotated among the 6 chambers throughout the exposure. For example, the mice that were in the exposure chamber no. 1 during the morning session were moved to the exposure chamber no. 2 during the afternoon session and so on. 
Plasma cotinine levels were assessed in blood collected from the saphenous vein of six mice (one from each exposure chamber) from each experimental group 15 min after the last daily exposure. Heparinized blood $(\sim 60 \mu \mathrm{L})$ was centrifuged at $15,000 \mathrm{rpm}$ for $10 \mathrm{~min}$ and plasma was collected and stored at $-20{ }^{\circ} \mathrm{C}$ until analysis. Cotinine levels were determined using the Cotinine One-Step ELISA Detection Kit (International Diagnostics Systems Corp., St. Joseph, MI) according to the manufacturer's specifications.

\section{Semen Sample Collection}

On the morning after the end of the 14-day exposure, 6 mice per group were euthanized by $\mathrm{CO}_{2}$ asphyxiation and each caudal epididymis was excised and minced into $2.5 \mathrm{~mL}$ of prewarmed M16 medium (Sigma, USA). The tissue suspension was incubated at $37{ }^{\circ} \mathrm{C}$ in $5 \% \mathrm{CO}_{2}$ for 5 minutes to allow for sperm dispersal. One sperm suspension was filtered through a $70 \mu \mathrm{m}$ cell strainer (BD Biosciences, USA) and stored frozen at $-80{ }^{\circ} \mathrm{C}$ for later use in the SCSA and comet analyses. Sperm from the second cauda were used for CASA analysis (unfiltered). Sperm counts were performed using a standard Neubauer hemocytometer (Hausser Scientific, USA) and no significant differences were found among the various groups (data not shown).

\section{Computer Assisted Sperm Analysis (CASA) of Sperm Motility}

We performed CASA analysis using the HTM-Ceros semen analyzer (Hamilton Thorne Research, USA) on samples that had been incubated at $37^{\circ} \mathrm{C}$ for 5 minutes. For each sample, 15 $\mu 1$ of sperm suspension were aliquoted into each of the two wells of a 2X-CEL $80 \mu \mathrm{m}$ deep chambered microscope slide (Hamilton Thorne Research) maintained at $37^{\circ} \mathrm{C}$ by a MiniTherm slide warmer. At least 4 fields $(0.5 \mathrm{sec}$ with a video frame rate of $60 \mathrm{~Hz})$ per chamber, or a minimum of 1000 motile sperm, were imaged through an Olympus $\mathrm{CH} 30$ microscope equipped with a $4 \mathrm{x}$ phase contrast objective and analyzed using the HTM-CEROS v10.9i software (Hamilton Thorne Research). We tracked the percentage of motile sperm (\% MOT), the percentage of forward, progressively motile sperm (\% PROG) as well as the velocities along their trajectories (VAP, VSL and VCL) and the amplitude of the lateral motion of the sperm head (ALH). The settings for the CASA analysis were as follows: frame rate: $60 \mathrm{~Hz} ; 30$ frames acquired/sample; minimum contrast: 20; minimum cell size: 4; non-motile head size: 13; non- 
motile head intensity: 75; static size limits: 0.13-2.43; static intensity limits: 0.10-1.62; static elongation limits: 5-100 and low phase setting: 23.

\section{Neutral Comet Assay of Sperm DNA Damage}

Frozen sperm aliquots were thawed for $1 \mathrm{~min}$ at $37^{\circ} \mathrm{C}$ and $10 \mu \mathrm{L}$ of sample was diluted with $70 \mu \mathrm{L}$ of $1 \times$ PBS with $5 \mathrm{mM}$ EDTA and mixed with $80 \mu \mathrm{L}$ of molten $1 \%$ low-melting agarose (Invitrogen \#15517-022) dissolved in $1 \mathrm{x}$ PBS and $5 \mathrm{mM}$ EDTA and kept at $37^{\circ} \mathrm{C}$. Fully frosted microscope slides ( $25 \times 75 \mathrm{~mm}$, Fisher, USA) were coated with $1.5 \%$ high melting point agarose (SIGMA, USA, A3768-25G) and allowed to dry overnight. A $30 \mu \mathrm{L}$ aliquot of sperm agarose solution was pipetted onto half of each prepared slide, coverslipped and incubated for 10 minutes on cold aluminum blocks at $4{ }^{\circ} \mathrm{C}$. A layer of molten $0.5 \%$ low-melting agarose was added to the slide and coverslipped, followed by another 10 -minute incubation at $4{ }^{\circ} \mathrm{C}$. The slides were then placed in a Coplin jar with lysis solution $(2.5 \mathrm{M} \mathrm{NaCl}, 100 \mathrm{mM}$ EDTA, $10 \mathrm{mM}$ Trizma Base, 1\% Triton X-100, $10 \mathrm{mM}$ DTT, $\mathrm{pH} 10.0$ ) for $1 \mathrm{hr}$ at $37{ }^{\circ} \mathrm{C}$. Proteinase K (Roche, USA) was added to a final concentration of $0.1 \mathrm{mg} / \mu \mathrm{L}$ and a further incubation was done for 2.5 hrs at $37^{\circ} \mathrm{C}$. Slides were dipped in a Coplin jar with 1 x TBE (89 mM Trizma Base, $89 \mathrm{mM}$ Boric acid, $20 \mathrm{mM}$ EDTA, pH 8.3) to wash off excess lysis buffer and placed in an electrophoresis chamber, submerged $(0.5 \mathrm{~cm}$ below surface $)$ in cooled $1 \mathrm{x}$ TBE buffer solution $\left(4^{\circ} \mathrm{C}\right)$. Electrophoresis was done at $35 \mathrm{~V}(\sim 15 \mathrm{~mA})$ for 10 minutes at $4{ }^{\circ} \mathrm{C}$. Slides were washed and dried with 70\% ethanol and stained with SYBR GOLD. Slides were coded and scored blindly on a Zeiss fluorescent microscope equipped with a 20x objective lens and with the aid of Comet analysis software (Komet 5.5, Andor Technology, NC).

\section{Sperm Chromatin Structural Assay (SCSA)}

Sperm chromatin integrity was assessed by the SCSA (35). Sperm cell suspension $\left(2 \times 10^{6}\right.$ cells $\left./ \mathrm{mL}\right)$ was diluted in TNE buffer $(150 \mathrm{mM} \mathrm{NaCl}, 10 \mathrm{mM}$ Tris, $1 \mathrm{mM}$ EDTA, pH 7.4) and sonicated to separate tails. A $200 \mu 1$ aliquot was mixed with $400 \mu 1$ of a low pH-detergent solution (0.01\% Triton X-100, $150 \mathrm{mM} \mathrm{NaCl}$, and $0.08 \mathrm{~N} \mathrm{HCl}, \mathrm{pH} 1.4)$. After $30 \mathrm{sec}$, sperm were incubated with the DNA-specific fluorescent dye acridine orange $(\mathrm{AO}, 6 \mathrm{mg} / \mathrm{mL})$ in a phosphate-citrate buffer (100 mM Citric acid, $200 \mathrm{mM} \mathrm{Na}_{2} \mathrm{HPO}_{4}, 1 \mathrm{mM}$ EDTA, $150 \mathrm{mM} \mathrm{NaCl}$, pH 6.0) and analyzed in a FACSort flow cytometer (Beckton Dickinson, San Jose, CA), 
equipped with an argon ion laser $(488 \mathrm{~nm})$. Visualization was done by multiparameter flow cytometric analysis after staining with $\mathrm{AO}$, which fluoresces green $(515-530 \mathrm{~nm})$ when intercalated with native, double-stranded DNA, and emits a red fluorescence $(>630 \mathrm{~nm})$ when intercalated with denatured, single-stranded DNA. The extent of DNA denaturation after acid treatment was quantified by the mean DNA Fragmentation Index (DFI), which is the ratio of red:(red + green) fluorescence. The population effect on the sperm was expressed as the proportion of sperm above a threshold DFI (\%DFI). Five thousand sperm were analyzed per sample at a flow rate of less than 200 cells/sec. Each sample was analyzed in duplicate. Data were acquired 3 min after initiation of staining in list-mode and analyzed using the SCSA Soft software (SCSA Diagnostics, Inc., Brookings, SD). An aliquot from a reference sample was analyzed in each measurement session as quality control.

\section{Effects on Fertilization and Early Embryonic Development}

Female superovulation was done according to a standard protocol (Marchetti et al., 2004). Females were mated overnight with exposed males at the end of the 14-day exposure period. Females were checked for vaginal plugs the morning after the induction of superovulation. Forty hours after fertilization, mated females were euthanized and embryos flushed from the uterine horns into Hanks' balanced salt solution. Embryos were collected from at least eight mated females per group and classified based on their morphological appearance into: 4-cell, 3-cell, 2-cell, 1-cell and degenerated embryos. Because it was not always possible to discriminate between the presence of one or two polar bodies within the zona pellucida, we did not distinguish 1-cell embryos between unfertilized eggs (one polar body) and fertilized uncleaved eggs (two polar bodies). Analysis of the developmental stage reached by each embryo was used to distinguish between effects on fertilization or on embryonic development. An effect on fertilization was expected to increase the frequencies of embryos at the one-cell stage, while an effect on embryonic developmental was expected to decrease the frequencies of embryos that progressed beyond the 2-cell stage.

\section{Statistical Analysis}

The mean and standard error of the mean were used as descriptive statistics for most assays. The median of the data for Comet was computed for each technical replicate (50 sperm 
were scored on each slide, two slides were scored per sample) and the mean of these values was computed for each biological sample. Because of the non-Gaussian distribution of the data among animals in each group, a non-parametric multivariate 1-way ANOVA test was used for all endpoints, with significance set at $P \leq 0.05$. All analyses were performed using DataDesk XL software (Datadescription, Ithaca, NY). 


\section{RESULTS}

\section{Assessment of Tobacco Smoke Exposure}

Cotinine levels of blood plasma collected $15 \mathrm{~min}$ after the end of the last daily exposure were $15.7 \pm 2.9 ; 95.4 \pm 23.5 ; 3.3 \pm 1.2$ and $31.2 \pm 9.5 \mathrm{ng} / \mathrm{mL}$ for $3 \mathrm{MS} ; 16 \mathrm{MS} ; 3 \mathrm{SS}$ and $16 \mathrm{SS}$ exposures, respectively. Cotinine levels in the unexposed mice were below the detection levels of the assay (data not shown). For comparison, human serum cotinine levels are 200 to 700 $\mathrm{ng} / \mathrm{mL}$ for active smokers, $\sim 50 \mathrm{ng} / \mathrm{mL}$ for light active smokers (less than 5 cigarettes per day), and $<15 \mathrm{ng} / \mathrm{mL}$ for passive smokers (Seccareccia et al., 2003). Thus, the cotinine levels in mice after MS smoke exposure are at the lower end of human active smoking, while cotinine levels after SS smoke exposure are within the range found among human passive smokers.

\section{Sperm Motility Effects}

We used CASA to analyze the motility of sperm sampled from the cauda epididymis the day after the end of the 14-day exposure period. As shown in Table 1, there was a differential effect on sperm motility between MS and SS smoke. Exposures to MS smoke did not alter the percentages of motile sperm nor their kinematic parameters as compared to controls (Table 1). Conversely, both doses of SS smoke significantly reduced sperm movement. All kinematic measures were significantly reduced with respect to controls (percentage decreases: 11 - 8\% (VAP); $13-8 \%$ (VSL); $12-6 \%$ (VCL); 5\% (ALH), $P<0.05)$. Importantly, at the low dose of SS smoke there was a significant reduction in the percentages of both motile $(54 \% \mathrm{vs} .63 \%$ in controls, $P<0.05$, ANOVA) and progressive sperm (38 vs. $48 \%$ in controls, $P<0.005$ ). These findings were confirmed on a second set of males that were independently exposed to either MS and SS smoke (Table 1). The motility and major kinematics measurements for each mouse from the two independent experiments are shown in Figure 1. In both replicate experiments, the lower dose of SS produced the greatest decrease in the percentages of motile and progressively motile sperm and the difference in this latter parameter was statistically significant (3 SS vs. $16 \mathrm{SS} ; P=$ 0.02). These results indicate that SS smoke is more detrimental to sperm motility than MS smoke and that the response to SS smoke is non linear.

\section{Genetic Effects of SS and MS smoke in Sperm}


We investigated the effects of male exposure to tobacco smoke on sperm DNA integrity using the neutral comet assay, which detects mainly DNA double strand breaks and cross links (Fairbairn et al., 1995), and SCSA, which measures the susceptibility of sperm DNA to in situ acid-induced denaturation (Evenson and Melamed, 1983). The comet results (Table 2) indicated that \% DNA in comet tail was significantly increased with respect to controls only in the $16 \mathrm{MS}$ group $(21.6 \pm 1.0$ vs $17.1 \pm 0.4$ in controls, $P<0.005)$. Similar results were obtained for tail length or tail moment (TM) (Table 2). All three measures of sperm DNA damage were consistently higher in the 16 SS group than in controls, and the effect on TM was borderline significant ( $4.1 \pm 0.6$ vs. $3.1 \pm 0.2$ in controls; $P=0.06)$.

The SCSA results are shown in Table 3. Only the high dose of MS smoke significantly increased DNA fragmentation $(\% \mathrm{DFI}, 4.8 \pm 0.7$ vs. $3.0 \pm 0.4$ in controls; $\mathrm{P}<0.05)$. These results are consistent with the comet data. The high dose of MS also significantly increased mean DFI with respect to controls (184.6. \pm 4.8 vs. $169.3 \pm 3.2 ; \mathrm{P}<0.05$, Table 3$)$. Interestingly, both doses of SS smoke had higher levels of mean DFI with respect to controls (Table 3), although the increase at the highest dose of SS smoke did not reach statistical significance $(P=0.2$, ANOVA) because of large animal-to-animal variation.

These results suggest that MS smoke exposure caused sperm DNA breaks and affected chromatin integrity, while SS smoke affected only chromatin structural integrity.

\section{Effects on Fertilization and Early Embryonic Development}

We next determined whether paternal exposure to MS or SS smoke affected fertilization and early embryonic development. As shown in Table 4, both low doses of MS and SS smoke significantly reduced the number of 4-cell embryos from $80.9 \pm 2.3 \%$ in controls to $66.6 \pm 4.0 \%$ and $67.3 \pm 3.8 \%$ in animals exposed to $3 \mathrm{MS}$ and $3 \mathrm{SS}$ smoke, respectively $(\mathrm{P}<0.05$, ANOVA). Increasing the daily dose of tobacco smoke did not significantly increase the detrimental effect on embryonic development, as the frequencies of 4-cell embryos in matings with males exposed to the high doses of MS and SS smoke were similar to those found after mating males that received only 3 cigarettes per day.

To further characterize the stages of early development affected by paternal exposure to tobacco smoke, we classified each embryo into two groups: those that had gone through the $1^{\text {st }}$ cleavage division (1-Cl), which included 2-cell, 3-cell and 4-cell embryos; and those than had 
gone through the $2^{\text {nd }}$ cleavage division $(2-\mathrm{Cl}$ ), which included 3-cell and 4-cell embryos (Figure 2). As shown in Table 4, MS smoke significantly reduced both 1-Cl and 2-Cl rates, while SS smoke affected the 1-Cl rate only. Again, both doses of each type of smoke produced quantitatively similar results. These results suggested that paternal exposure to both MS and SS smoke affected fertilization, while MS smoke only affected embryonic development. 


\section{DISCUSSION}

We investigated the effects of male exposure to MS and SS smoke on sperm function and DNA integrity and the consequences for fertilization and early embryonic development using a mouse model. As summarized in Table 5, we report that: (i) only SS smoke decreased sperm motility; (ii) only MS smoke increased sperm DNA breaks; (iii) both types of tobacco smoke negatively affected sperm chromatin integrity and reduced fertilization; and (iv) MS smoke reduced early embryonic development rates after mating exposed males with unexposed females. Our results suggest that male germ cells show differential sensitivity to MS and SS smoke and that, consistent with previous data for first-hand smoke, male exposure to second-hand smoke before fertilization is likely to have detrimental consequences for human reproduction.

It is well established that first-hand smoke has significant effects on male germ cells (The Practice Committee of the American Society for Reproductive Medicine, 2004; Soares and Melo, 2008), while the reproductive effects of second-hand smoke are largely unknown. This is in part caused by the complexities of epidemiological studies, including the difficulties in objectively measuring second-hand smoke exposures, confounding exposures and the lack of parallel completely unexposed control populations (U.S. Department of Health and Human Services, 2006). Also, maternal exposure to cigarette smoke is often a confounding factor that makes the assessment of the effects of paternal exposure to second-hand smoke on fertilization and early embryonic development particularly challenging. We used an animal model to circumvent some of these challenges and assess the effects of second-hand smoke on sperm function and DNA integrity and used plasma cotinine levels as a marker of cigarette-smoke exposure. Cotinine is the most common biomarker of tobacco smoke exposure in humans (Seccareccia et al., 2003). Based on measured plasma cotinine levels, the exposure regimen utilized in this study produced cotinine levels that matched those found in human light smokers and passive smokers after exposure to MS and SS smoke, respectively. Direct extrapolation of cotinine levels between mouse and humans, however, requires caution because differences in oxidative metabolism capacity among mouse strains and between species (Siu and Tyndale, 2007), as well as among human ethnicities (Caraballo et al., 1998), can affect cotinine levels (Hukkanen et al., 2005).

Sperm motility assessed by CASA is a common measure of sperm quality in fertility clinics (Oehninger et al., 2000) and low percent motile sperm (\%MOT) has been associated with reduced fertility (Chapin et al., 1997). Reduction in sperm motility has been associated with 
smoking >20 cigarettes/day (Ramlau-Hansen et al., 2007). We found that exposure to MS smoke during the last two weeks of mouse sperm development did not affect sperm motility. These results suggest that our exposure was not high enough, in terms of daily dose of cigarette smoke, or long enough, in terms of number of days of exposure, to affect sperm motility. Conversely, significant reductions in motility parameters were observed after exposure to SS smoke. All kinematic measures of sperm motion were negatively affected, including VCL, VSL, VAP, and ALH (Table 1 and Figure 1). The latter has been associated with impaired ability of the sperm to penetrate through the cumulus cells and reach the egg (Barlow et al., 1991; Verstegen et al., 2002). Interestingly, these effects were apparent even after exposing mice to as little as 20 min of SS smoke a day for 2 weeks, an exposure regimen that produced cotinine plasma levels similar to those found in human passive smokers.

Exposures of mice to a variety of environmental agents, including components of tobacco smoke, have been shown to affect sperm motility (Chapin et al., 1997; Elangovan et al., 2006). Our study does not provide information on which tobacco smoke component may be affecting sperm motility. Because exposure of mature mouse sperm in vitro to either nicotine or cotinine does not affect sperm motility (Gandini et al., 1997), our results suggest that other SS smokespecific toxicants are responsible for the observed effects. Alternatively, the sensitive window for affecting sperm motility may be during their passage through the epididymis, when they undergo morphological and biochemical changes that generate the motility necessary for the sperm to pass the uterotubal junction and for successful fertilization (Soler et al., 1994). The lack of an effect of MS smoke further suggests that the reduction in sperm motility after exposure to SS smoke is due to toxicants that are present at higher levels in SS smoke. One such a toxicant is carbon monoxide (CO), which is found at levels that are 2.8-fold higher in SS smoke than in MS smoke (Committee on Passive Smoking, 1986). CO inhibits the mitochondrial respiratory chain by interfering with the cytochrome c oxidase (Alonso et al., 2003) and may affect sperm motility by altering mitochondria functions and reducing the energy stores needed for motility. Ex vivo studies have shown that fully mature sperm are not susceptible to CO (Makler et al., 1993), indicating that $\mathrm{CO}$ may affect the acquisition of sperm motility in the epididymis. Additional toxicants that are present at higher levels in SS smoke than MS smoke and that have been implicated with reduced sperm motility include reactive oxygen species (Kao et al., 2008; Tremellen, 2008) and cadmium (Xu et al., 2001; Kumosani et al., 2008). 
The finding that the low dose of SS smoke produced the strongest effect on sperm motility was unexpected. Therefore, we repeated the experiments with another set of males. The results of this second analysis (Table 1 and Figure 1) confirmed the original finding that exposure of mice to SS smoke generated by 3 cigarettes per day resulted in a larger decrease in sperm motility and kinematics parameters than 16 cigarettes per day. Additional work is required to characterize the shape of the dose-response to SS smoke and elucidate the mechanism(s) for this non-linear response. Large and rapid onset of cardiovascular effects of second-hand smoke not predicted by a simple linear dose-response relationship have also been reported (Barnoya and Glantz, 2005b). Our results show that even very short exposures ( $20 \mathrm{~min} /$ day $)$ to second-hand smoke can affect sperm motility.

A recently published study reported that exposure to environmental tobacco smoke (ETS) during a six-month period did not affect sperm motility in rhesus monkeys (Hung et al., 2009). Besides possible species-associated differences in the sensitivity to tobacco smoke, the two studies differed in key experimental variables that could account for the contrasting results. A mixture of MS and SS smoke (9:1) was utilized by (Hung et al., 2009), while we utilized SS smoke only. As our results show a lack of effect of MS smoke on sperm motility, the inclusion of MS smoke in the exposure mixture experienced by the monkeys may have diluted the effect of SS smoke. Also, based on TSP measurements, our SS smoke exposure was 2- to 4-fold higher than that used in the monkey study. Therefore, our mice experienced a higher CO concentration. In addition, even the study of (Hung et al., 2009) provides some support for an effect of ETS on sperm motility. Several kinematics parameters, including VAP and VSL, did show a decrease with increased duration of exposure and, notably, the first semen sample collected after the beginning of the exposure to ETS, which is the one directly comparable with our study, had the lowest sperm motility value among all collected samples. Finally, several aspects of semen quality (semen volume and \% of motile sperm) showed a trend for an increase over time, which probably reflected the monkeys reaching full sexual maturity in the later stages of the study of Hung et al. (2009). In the absence of concurrent unexposed monkeys, it cannot be excluded that these parameters could have increased even higher without exposure to ETS. Our results in the mouse show that exposure to SS smoke, admittedly at doses seldom experienced by human nonsmokers, decreases sperm motility with respect to unexposed mice. 
Increases in sperm chromosomal abnormalities (Robbins et al., 1997; Rubes et al., 1998; Shi et al., 2001), sperm DNA damage as measured by comet (Hoffmann et al., 2005) TUNEL (Sepaniak et al., 2006) and SCSA (Potts et al., 1999) assays have all been reported in human smokers. Also, it was recently shown in mice that MS smoke induced mutations at specific repeat DNA loci in sperm (Yauk et al., 2007). We found that only the high dose of MS smoke produced a significant increase in the amount of DNA damage detected by the comet assay. This finding was corroborated by the SCSA results, which also showed a significant increase in \%DFI and mean DFI at the high dose of MS smoke. Increases in \%DFI are thought to arise, at least in part, from DNA breaks (Evenson and Wixon, 2006). Our comet and SCSA results confirm the human findings that MS smoke induces sperm DNA breaks and chromatin structural defects. These sperm DNA defects have been linked to chromosomal abnormalities in zygotic metaphases (Estop et al., 1993), disrupted embryonic development, the lack of pregnancy after fertilization (D'Occhio et al., 2007), and failures encountered during assisted reproduction (BoeHansen et al., 2006; Bungum et al., 2007).

Our study contributes to the understanding of the genotoxic effects of second-hand smoke on the male germline (Husgafvel-Pursiainen, 2004; U.S. Department of Health and Human Services, 2006). We found that SS smoke failed to induce statistically significant increases in sperm DNA breaks as measured by the comet and SCSA assays. However, we did observe chromatin effects in the sperm of mice exposed to SS smoke. A statistically significant increase in mean DFI was found after exposure to the low dose of SS. The high dose of SS smoke did not reach statistical significance because of high animal-to-animal variation. These results indicate that, as for MS smoke, SS smoke disrupted chromatin remodeling during spermiogenesis resulting in increased chromatin relaxation in mature sperm. Overall, these results suggest that $\mathrm{SS}$ is less genotoxic to male germ cells than MS smoke. Although the number of known compounds in each type of smoke is very large (Borgerding and Klus, 2005; U.S. Department of Health and Human Services, 2006), screenings have identified some known genotoxins with differential concentrations between the two types of smoke (Fowles and Dybing, 2003). The differential genotoxic effects observed in our study merits further assessment.

Male exposure to either type of tobacco smoke before fertilization significantly reduced the frequencies of mouse embryos that reached the 4-cell stage in matings with untreated females (Table 4). Although this reduction was similar among the exposure groups, analysis of the 
developmental stage reached by each embryo indicated that MS smoke reduced the number of embryos that made it past the 1-Cl and also the 2-Cl division, while SS smoke affected only the number of embryos that made it past the 1-Cl division. Taking into account the findings of the sperm assays, these results suggest that the reduction in 4-cell embryos observed after MS and SS smoke exposure was primarily the consequences of increased DNA damage and reduced sperm motility, respectively. It has also been suggested that exposure to cigarette smoke results in decreased sperm membrane permeability and function (Sofikitis et al., 2000) and sperm acrosin activity (Sofikitis et al., 1995), which are necessary for sperm capacitation and hyperactivation within the female reproductive tract and penetrating the zona pellucida of the oocyte, respectively. Additional studies are needed to determine whether the reduced fertilization rates observed in our study are the consequence of reduced motility, abnormal sperm capacitation and acrosin activity, or a combination of all.

Our results with MS smoke confirm previous findings in rats that showed significant decreases in fertilization and embryonic cleavage (Kapawa et al., 2004). However, the effects observed in the current study with lower exposure levels (cotinine level of $95.4 \pm 23.5 \mathrm{ng} / \mathrm{mL}$ vs. $180 \pm 86 \mathrm{ng} / \mathrm{mL}$ in the rat study) and a much shorter duration of exposure (2 weeks vs. 10 weeks) indicate a greater sensitivity of the male germline to tobacco smoke than previously thought. Delayed early embryonic development has been associated with the generation of blastocysts with lowered capacity for implantation and reduced numbers of live offspring (Kapawa et al., 2004). Our results suggest that paternal exposure to MS smoke alters sperm genetic or epigenetic factors that affect the developmental capacity of the fertilized embryo. In addition, ours is the first study to report that male exposure to second-hand smoke affects the fertilizing capacity of sperm.

In summary, we found that SS smoke exposure has deleterious effects on the male germline that differ from those induced by MS smoke. Our results indicate that SS smoke is potentially a cause of reduced reproductive competency by affecting sperm motility and fertilization rates. Our findings have relevance for prospective fathers because they suggest that their contribution to healthy pregnancies require, not only to abstaining from smoking, but also avoiding exposure to second-hand smoke. 


\section{ACKNOWLEDGEMENTS}

We thank Dr Andrew J Wyrobek for critical reading of the manuscript, Dr. Lara Gundel for help with the total suspended particulate measurements, and MJ Solís-Heredia for technical assistance. Work performed under the auspices of the U.S. DOE by the Lawrence Berkeley National Laboratory under contract DE-AC02-05CH1123 with funding support from the California Tobacco Related Disease Research Program grant 13RT-0140A to FM. 


\section{REFERENCES}

Alonso, J.R., Cardellach, F., Lopez, S., Casademont, J., Miro, O., 2003. Carbon monoxide specifically inhibits cytochrome c oxidase of human mitochondrial respiratory chain. Pharmacol Toxicol 93, 142-146.

Barlow, P., Delvigne, A., Van Dromme, J., Van Hoeck, J., Vandenbosch, K., Leroy, F., 1991. Predictive value of classical and automated sperm analysis for in-vitro fertilization. Hum Reprod 6, 1119-1124.

Barnoya, J., Glantz, S.A., 2005a. The tobacco industry's worldwide ETS consultant project: European and Asian components. Eur J Pub Health 16, 69-77.

Barnoya, J., Glantz, S.A., 2005b. Cardiovascular effects of secondhand smoke: nearly as large as smoking. Circulation 111, 2684-2698.

Boe-Hansen, G.B., Fedder, J., Ersboll, A.K., Christensen, P., 2006. The sperm chromatin structure assay as a diagnostic tool in the human fertility clinic. Hum Reprod 21, 15761582.

Borgerding, M., Klus, H., 2005. Analysis of complex mixtures--cigarette smoke. Exp Toxicol Pathol 57 Suppl 1, 43-73.

Bungum, M., Humaidan, P., Axmon, A., Spano, M., Bungum, L., Erenpreiss, J., Giwercman, A., 2007. Sperm DNA integrity assessment in prediction of assisted reproduction technology outcome. Hum Reprod 22, 174-179.

California Environmental Protection Agency, 2005. Health Effects Assessment for Environmental Tobacco Smoke, Sacramento, CA.

Caraballo, R.S., Giovino, G.A., Pechacek, T.F., Mowery, P.D., Richter, P.A., Strauss, W.J., Sharp, D.J., Eriksen, M.P., Pirkle, J.L., Maurer, K.R., 1998. Racial and ethnic differences in serum cotinine levels of cigarette smokers: Third National Health and Nutrition Examination Survey, 1988-1991. Jama 280, 135-139.

Chang, J.S., Selvin, S., Metayer, C., Crouse, V., Golembesky, A., Buffler, P.A., 2006. Parental smoking and the risk of childhood leukemia. Am J Epidemiol 163, 1091-1100.

Chapin, R.E., Sloane, R.A., Haseman, J.K., 1997. The relationships among reproductive endpoints in Swiss mice, using the reproductive assessment by Continuous Breeding database. Fundam Appl Toxicol 38, 129-142.

Committee on Passive Smoking, 1986. Environmental Tobacco smoke: measuring exposures and assessing health effects. National Academy Press, Washington, D.C.

D'Occhio, M.J., Hengstberger, K.J., Johnston, S.D., 2007. Biology of sperm chromatin structure and relationship to male fertility and embryonic survival. Anim Reprod Sci 101, 1-17.

Elangovan, N., Chiou, T.J., Tzeng, W.F., Chu, S.T., 2006. Cyclophosphamide treatment causes impairment of sperm and its fertilizing ability in mice. Toxicology 222, 60-70.

Estop, A.M., Munne, S., Jost, L.K., Evenson, D.P., 1993. Studies on sperm chromatin structure alterations and cytogenetic damage of mouse sperm following in vitro incubation. Studies on in vitro-incubated mouse sperm. J Androl 14, 282-288.

Evenson, D.P., Melamed, M.R., 1983. Rapid analysis of normal and abnormal cell types in human semen and testis biopsies by flow cytometry. J Histochem Cytochem 31, 248-253.

Evenson, D.P., Wixon, R., 2006. Clinical aspects of sperm DNA fragmentation detection and male infertility. Theriogenology 65, 979-991.

Fairbairn, D.W., Olive, P.L., O'Neill, K.L., 1995. The comet assay: a comprehensive review. Mutat Res 339, 37-59. 
Ford, W.C., North, K., Taylor, H., Farrow, A., Hull, M.G., Golding, J., 2000. Increasing paternal age is associated with delayed conception in a large population of fertile couples: evidence for declining fecundity in older men. The ALSPAC Study Team (Avon Longitudinal Study of Pregnancy and Childhood). Hum Reprod 15, 1703-1708.

Fowles, J., Dybing, E., 2003. Application of toxicological risk assessment principles to the chemical constituents of cigarette smoke. Tob Control 12, 424-430.

Fraga, C.G., Motchnik, P.A., Wyrobek, A.J., Rempel, D.M., Ames, B.N., 1996. Smoking and low antioxidant levels increase oxidative damage to sperm DNA. Mutat Res 351, 199203.

Gandini, L., Lombardo, F., Lenzi, A., Culasso, F., Pacifici, R., Zuccaro, P., Dondero, F., 1997. The in-vitro effects of nicotine and cotinine on sperm motility. Hum Reprod 12, 727-733.

Haglund, B., Cnattingius, S., 1990. Cigarette smoking as a risk factor for sudden infant death syndrome: a population-based study. Am J Public Health 80, 29-32.

Hoffmann, H., Hogel, J., Speit, G., 2005. The effect of smoking on DNA effects in the comet assay: a meta-analysis. Mutagenesis 20, 455-466.

Horak, S., Polanska, J., Widlak, P., 2003. Bulky DNA adducts in human sperm: relationship with fertility, semen quality, smoking, and environmental factors. Mutat Res 537, 53-65.

Hughes, E.G., Brennan, B.G., 1996. Does cigarette smoking impair natural or assisted fecundity? Fertil Steril 66, 679-689.

Hukkanen, J., Jacob, P., 3rd, Benowitz, N.L., 2005. Metabolism and disposition kinetics of nicotine. Pharmacol Rev 57, 79-115.

Hung, P., Froenicke, L., Lin, C.Y., Lyons, L.A., Miller, M.G., Pinkerton, K.E., VandeVoort, C.A., 2009. Effects of environmental tobacco smoke in vivo on rhesus monkey semen quality, sperm fucntion, and sperm metabolism. Reprod Toxicol doi:10.1016/j.reprotox.2008.12.007.

Husgafvel-Pursiainen, K., 2004. Genotoxicity of environmental tobacco smoke: a review. Mutat Res 567, 427-445.

Ji, B.T., Shu, X.O., Linet, M.S., Zheng, W., Wacholder, S., Gao, Y.T., Ying, D.M., Jin, F., 1997. Paternal cigarette smoking and the risk of childhood cancer among offspring of nonsmoking mothers. J Natl Cancer Inst 89, 238-244.

Kao, S.H., Chao, H.T., Chen, H.W., Hwang, T.I., Liao, T.L., Wei, Y.H., 2008. Increase of oxidative stress in human sperm with lower motility. Fertil Steril 89, 1183-1190.

Kapawa, A., Giannakis, D., Tsoukanelis, K., Kanakas, N., Baltogiannis, D., Agapitos, E., Loutradis, D., Miyagawa, I., Sofikitis, N., 2004. Effects of paternal cigarette smoking on testicular function, sperm fertilizing capacity, embryonic development, and blastocyst capacity for implantation in rats. Andrologia 36, 57-68.

Kimmins, S., Sassone-Corsi, P., 2005. Chromatin remodelling and epigenetic features of germ cells. Nature 434, 583-589.

Klonoff-Cohen, H.S., Edelstein, S.L., Lefkowitz, E.S., Srinivasan, I.P., Kaegi, D., Chang, J.C., Wiley, K.J., 1995. The effect of passive smoking and tobacco exposure through breast milk on sudden infant death syndrome. Jama 273, 795-798.

Kumosani, T.A., Elshal, M.F., Al-Jonaid, A.A., Abduljabar, H.S., 2008. The influence of smoking on semen quality, seminal microelements and Ca2+-ATPase activity among infertile and fertile men. Clin Biochem 41, 1199-1203.

Leduc, F., Nkoma, G.B., Boissonneault, G., 2008. Spermiogenesis and DNA repair: a possible etiology of human infertility and genetic disorders. Syst Biol Reprod Med 54, 3-10. 
Makler, A., Reiss, J., Stoller, J., Blumenfeld, Z., Brandes, J.M., 1993. Use of a sealed minichamber for direct observation and evaluation of the in vitro effect of cigarette smoke on sperm motility. Fertil Steril 59, 645-651.

Marchetti, F., Bishop, J.B., Cosentino, L., Moore, D., 2nd, Wyrobek, A.J., 2004. Paternally transmitted chromosomal aberrations in mouse zygotes determine their embryonic fate. Biol Reprod 70, 616-624.

Marchetti, F., Wyrobek, A.J., 2008. DNA repair decline during mouse spermiogenesis results in the accumulation of heritable DNA damage. DNA Repair (Amst) 7, 572-581.

Meeker, J.D., Missmer, S.A., Cramer, D.W., Hauser, R., 2007. Maternal exposure to secondhand tobacco smoke and pregnancy outcome among couples undergoing assisted reproduction. Hum Reprod 22, 337-345.

Mohtashamipur, E., Mohtashamipur, A., Germann, P.G., Ernst, H., Norpoth, K., Mohr, U., 1990. Comparative carcinogenicity of cigarette mainstream and sidestream smoke condensates on the mouse skin. J Cancer Res Clin Oncol 116, 604-608.

Neal, M.S., Hughes, E.G., Holloway, A.C., Foster, W.G., 2005. Sidestream smoking is equally as damaging as mainstream smoking on IVF outcomes. Hum Reprod 20, 2531-2535.

Nelson, E., Goubet-Wiemers, C., Guo, Y., Jodscheit, K., 1999. Maternal passive smoking during pregnancy and foetal developmental toxicity. Part 2: histological changes. Hum Exp Toxicol 18, 257-264.

Oehninger, S., Franken, D.R., Sayed, E., Barroso, G., Kolm, P., 2000. Sperm function assays and their predictive value for fertilization outcome in IVF therapy: a meta-analysis. Hum Reprod Update 6, 160-168.

Potts, R.J., Newbury, C.J., Smith, G., Notarianni, L.J., Jefferies, T.M., 1999. Sperm chromatin damage associated with male smoking. Mutat Res 423, 103-111.

Rajini, P., Last, J.A., Pinkerton, K.E., Hendrickx, A.G., Witschi, H., 1994. Decreased fetal weights in rats exposed to sidestream cigarette smoke. Fundam Appl Toxicol 22, 400404.

Ramlau-Hansen, C.H., Thulstrup, A.M., Aggerholm, A.S., Jensen, M.S., Toft, G., Bonde, J.P., 2007. Is smoking a risk factor for decreased semen quality? A cross-sectional analysis. Hum Reprod 22, 188-196.

Robbins, W.A., Vine, M.F., Truong, K.Y., Everson, R.B., 1997. Use of fluorescence in situ hybridization (FISH) to assess effects of smoking, caffeine, and alcohol on aneuploidy load in sperm of healthy men. Environ Mol Mutagen 30, 175-183.

Rubes, J., Lowe, X., Moore, D., 2nd, Perreault, S., Slott, V., Evenson, D., Selevan, S.G., Wyrobek, A.J., 1998. Smoking cigarettes is associated with increased sperm disomy in teenage men. Fertil Steril 70, 715-723.

Sebrié, E.M., Barnoya, J., Pérez-Stable, E.J., Glantz, S.A., 2005. Tobacco industry successfully prevented tobacco control legislation in Argentina. Tob Cont 14, e2.

Seccareccia, F., Zuccaro, P., Pacifici, R., Meli, P., Pannozzo, F., Freeman, K.M., Santaquilani, A., Giampaoli, S., 2003. Serum cotinine as a marker of environmental tobacco smoke exposure in epidemiological studies: the experience of the MATISS project. Eur J Epidemiol 18, 487-492.

Sepaniak, S., Forges, T., Gerard, H., Foliguet, B., Bene, M.C., Monnier-Barbarino, P., 2006. The influence of cigarette smoking on human sperm quality and DNA fragmentation. Toxicology 223, 54-60. 
Shen, H.M., Chia, S.E., Ni, Z.Y., New, A.L., Lee, B.L., Ong, C.N., 1997. Detection of oxidative DNA damage in human sperm and the association with cigarette smoking. Reprod Toxicol 11, 675-680.

Shi, Q., Ko, E., Barclay, L., Hoang, T., Rademaker, A., Martin, R., 2001. Cigarette smoking and aneuploidy in human sperm. Mol Reprod Dev 59, 417-421.

Shields, M., 2007. Smoking-prevalence, bans and exposure to second-hand smoke. Health Rep $18,67-85$

Siu, E.C., Tyndale, R.F., 2007. Characterization and comparison of nicotine and cotinine metabolism in vitro and in vivo in DBA/2 and C57BL/6 mice. Mol Pharmacol 71, 826834.

Soares, S.R., Melo, M.A., 2008. Cigarette smoking and reproductive function. Curr Opin Obstet Gynecol 20, 281-291.

Sofikitis, N., Miyagawa, I., Dimitriadis, D., Zavos, P., Sikka, S., Hellstrom, W., 1995. Effects of smoking on testicular function, semen quality and sperm fertilizing capacity. J Urol 154, 1030-1034.

Sofikitis, N., Takenaka, M., Kanakas, N., Papadopoulos, H., Yamamoto, Y., Drakakis, P., Miyagawa, I., 2000. Effects of cotinine on sperm motility, membrane function, and fertilizing capacity in vitro. Urol Res 28, 370-375.

Soler, C., Yeung, C.H., Cooper, T.G., 1994. Development of sperm motility patterns in the murine epididymis. Int J Androl 17, 271-278.

Taylor, J.A., Sanderson, M., 1995. A reexamination of the risk factors for the sudden infant death syndrome. J Pediatr 126, 887-891.

The Practice Committee of the American Society for Reproductive Medicine, 2004. Smoking and infertility. Fertil Steril 81, 1181-1186.

Tremellen, K., 2008. Oxidative stress and male infertility--a clinical perspective. Hum Reprod Update 14, 243-258.

U.S. Department of Health and Human Services, 2006. The Health Consequences of Involuntary Exposure to Tobacco Smoke: A Report of the Surgeon General, Atlanta, GA.

Venners, S.A., Wang, X., Chen, C., Wang, L., Chen, D., Guang, W., Huang, A., Ryan, L., O'Connor, J., Lasley, B., Overstreet, J., Wilcox, A., Xu, X., 2004. Paternal smoking and pregnancy loss: a prospective study using a biomarker of pregnancy. Am J Epidemiol 159, 993-1001.

Verstegen, J., Iguer-Ouada, M., Onclin, K., 2002. Computer assisted semen analyzers in andrology research and veterinary practice. Theriogenology 57, 149-179.

Witschi, H., Lundgaard, S.M., Rajini, P., Hendrickx, A.G., Last, J.A., 1994. Effects of exposure to nicotine and to sidestream smoke on pregnancy outcome in rats. Toxicol Lett 71, 279286.

Xu, L.C., Wang, S.Y., Yang, X.F., Wang, X.R., 2001. Effects of cadmium on rat sperm motility evaluated with computer assisted sperm analysis. Biomed Environ Sci 14, 312-317.

Yauk, C.L., Berndt, M.L., Williams, A., Rowan-Carroll, A., Douglas, G.R., Stampfli, M.R., 2007. Mainstream tobacco smoke causes paternal germ-line DNA mutation. Cancer Res 67, 5103-5106. 


\section{FIGURE LEGENDS}

Figure 1: Sperm motility and selected kinematics parameters after exposure of male mice to either mainstream (MS) or sidestream (SS) smoke. Each datapoint represents a mouse. Datapoints from the first and second experiment are shown in black and white, respectively. Short horizontal bars indicate the mean value for each parameter.

Figure 2: Schema and timing of the early stages of mouse development. Normal embryos are expected to have reached the 4-cell stage at the time of analysis. Embryonic divisions that were affected after paternal exposure to tobacco smoke are indicated by Xs with examples of the corresponding defects. One-cell embryos and degenerated embryos represent unfertilized eggs and fertilized egg that arrested before the first cleavage division. Two-cell embryos represent embryos in which both blastomeres failed to undergo the second cleavage division and were considered arrested. Three-cell embryos represent embryos in which a blastomere has not gone through the secondcleavage division and were considered delayed. 
Table 1. Sperm motility characteristics after male exposure to mainstream (MS) or sidestream (SS) tobacco smoke measured by the Computer Assisted Sperm Assay (CASA).

\begin{tabular}{|c|c|c|c|c|c|c|c|}
\hline Exposure $^{a}$ & No. mice & $\% \mathrm{MOT}^{\mathrm{b}}$ & $\% \mathrm{PROG}^{\mathrm{b}}$ & $\mathrm{VAP}^{\mathrm{b}}$ & $\mathrm{VSL}^{\mathrm{b}}$ & $\mathrm{VCL}^{\mathrm{b}}$ & $\mathrm{ALH}^{\mathrm{b}}$ \\
\hline \multirow[t]{2}{*}{ Controls } & 20 & $63 \pm 3$ & $48 \pm 2$ & $158 \pm 2$ & $109 \pm 2$ & $304 \pm 4$ & $16.5 \pm 0.2$ \\
\hline & & $(64,63)$ & $(49,46)$ & $(162,152)$ & $(112,104)$ & $(313,288)$ & $(16.8,16.0)$ \\
\hline \multirow[t]{2}{*}{$3 \mathrm{MS}$} & 12 & $63 \pm 5$ & $46 \pm 4$ & $163 \pm 4$ & $113 \pm 3$ & $304 \pm 7$ & $16.5 \pm 0.3$ \\
\hline & & $(60,67)$ & $(47,45)$ & $(161,164)$ & $(115,111)$ & $(310,298)$ & $(16.5,16.5)$ \\
\hline \multirow[t]{2}{*}{$16 \mathrm{MS}$} & 12 & $59 \pm 3$ & $43 \pm 3$ & $159 \pm 5$ & $106 \pm 4$ & $305 \pm 10$ & $16.9 \pm 0.4$ \\
\hline & & $(58,60)$ & $(46,40)$ & $(158,161)$ & $(109,103)$ & $(308,302)$ & $(16.4,17.5)$ \\
\hline \multirow[t]{2}{*}{$3 \mathrm{SS}$} & 12 & $54 \pm 3 *$ & $38 \pm 2 *$ & $141 \pm 3 * *$ & $95 \pm 2 * *$ & $268 \pm 7 * *$ & $15.6 \pm 0.3 *$ \\
\hline & & $(51,57)$ & $(39,36)$ & $(143,140)$ & $(97,93)$ & $(279,257)$ & $(15.7,15.5)$ \\
\hline \multirow[t]{2}{*}{$16 \mathrm{SS}$} & 12 & $61 \pm 2$ & $45 \pm 2$ & $146 \pm 3 * *$ & $100 \pm 3 *$ & $284 \pm 6 *$ & $15.6 \pm 0.2 * *$ \\
\hline & & $(58,65)$ & $(44,46)$ & $(149,144)$ & $(102,98)$ & $(291,277)$ & $(15.6,15.7)$ \\
\hline
\end{tabular}

${ }^{\mathrm{a}}$ The experimental groups are identified by the type of smoke (MS or SS) and the number of daily cigarettes (3 or 16) utilized for the exposures.

${ }^{b}$ Mean \pm SE for the total number of mice analyzed. In parentheses are the averages from each of the two separate experiments with 6 mice per treatment group conducted 9 months apart. Velocity parameters are given in $\mu \mathrm{m} / \mathrm{sec}$.

$* \mathrm{P}<0.05$ vs. controls (ANOVA, 95\% CI)

** $\mathrm{P}<0.005$ vs. controls (ANOVA vs. controls, $95 \% \mathrm{CI}$ 
Table 2. Sperm DNA damage after exposure of male mice to mainstream (MS) and sidestream (SS) tobacco smoke measured the neutral comet assay.

\begin{tabular}{ccccc}
\hline Exposure $^{\mathrm{a}}$ & No. mice & \% Tail DNA & Tail Length $(\mu \mathrm{m})$ & Tail Moment $^{\mathrm{b}}$ \\
\hline CTR & 11 & $17.1 \pm 0.4$ & $18.0 \pm 0.7$ & $3.1 \pm 0.2$ \\
$3 \mathrm{MS}$ & 6 & $17.8 \pm 1.1$ & $17.8 \pm 1.2$ & $3.2 \pm 0.4$ \\
$16 \mathrm{MS}$ & 6 & $21.6 \pm 1.0^{*}$ & $24.4 \pm 1.8^{*}$ & $5.4 \pm 0.6^{*}$ \\
$3 \mathrm{SS}$ & 6 & $16.8 \pm 1.1$ & $17.5 \pm 1.5$ & $3.1 \pm 0.5$ \\
$16 \mathrm{SS}$ & 6 & $18.9 \pm 1.1$ & $20.7 \pm 2$ & $4.1 \pm 0.6$
\end{tabular}

${ }^{\mathrm{a}}$ The experimental groups are identified by the type of smoke (MS or SS) and the number of daily cigarettes (3 or 16) utilized for the exposures.

${ }^{\mathrm{b}}$ Tail length $\mathrm{x}(\%$ Tail DNA/100)

$* P<0.005$ vs. controls (ANOVA, $95 \% \mathrm{CI}$ ) 
Table 3. Sperm chromatin integrity after male exposure to mainstream (MS) and sidestream (SS) tobacco smoke measured by SCSA.

\begin{tabular}{cccc}
\hline Exposure $^{\mathrm{a}}$ & \# Animals & \%DFI \pm SE & mean DFI \pm SE \\
\hline CTR & 14 & $3.01 \pm 0.4$ & $169.3 \pm 3.2$ \\
$3 \mathrm{MS}$ & 6 & $2.95 \pm 0.4$ & $176.3 \pm 3.8$ \\
$16 \mathrm{MS}$ & 6 & $4.85 \pm 0.7 *$ & $184.6 \pm 4.8^{*}$ \\
$3 \mathrm{SS}$ & 6 & $3.74 \pm 0.7$ & $188.6 \pm 7.9 *$ \\
$16 \mathrm{SS}$ & 6 & $4.16 \pm 1.1$ & $180.7 \pm 10.4$
\end{tabular}

${ }^{\mathrm{a}}$ The experimental groups are identified by the type of smoke (MS or SS) and the number of daily cigarettes ( 3 or 16) utilized for the exposures.

* $P<0.05$ vs. controls (1-way ANOVA, 95\% CI) 
Table 4. Fertilization and early embryonic development in unexposed female mice after paternal exposure to mainstream (MS) and sidestream (SS) tobacco smoke.

\begin{tabular}{|c|c|c|c|c|c|}
\hline $\begin{array}{c}\text { Paternal } \\
\text { exposure }^{\mathrm{a}}\end{array}$ & $\begin{array}{c}\text { Number of } \\
\text { Females }\end{array}$ & $\begin{array}{l}\text { Number of } \\
\text { Embryos }\end{array}$ & $\begin{array}{c}\text { 4-Cell Embryos } \\
\qquad(\% \pm \mathrm{SE})\end{array}$ & $\begin{array}{c}\text { 1st Cleavage rate } \\
(\% \pm \mathrm{SE})\end{array}$ & $\begin{array}{c}\text { 2nd Cleavage rate } \\
\qquad(\% \pm \mathrm{SE})\end{array}$ \\
\hline CTR & 11 & 414 & $80.9 \pm 2.3$ & $88.9 \pm 2.3$ & $96.2 \pm 1.0$ \\
\hline $3 \mathrm{MS}$ & 9 & 359 & $66.6 \pm 4.0 * *$ & $75.8 \pm 3.1 * *$ & $91.2 \pm 2.6^{*}$ \\
\hline $16 \mathrm{MS}$ & 10 & 418 & $64.4 \pm 3.5^{* *}$ & $76.8 \pm 3.3^{* *}$ & $87.2 \pm 3.8^{*}$ \\
\hline $3 \mathrm{SS}$ & 9 & 346 & $67.3 \pm 3.8^{* *}$ & $76.3 \pm 3.3^{* *}$ & $93.6 \pm 1.4$ \\
\hline $16 \mathrm{SS}$ & 8 & 315 & $70.2 \pm 3.1^{*}$ & $75.6 \pm 2.8^{* *}$ & $95.8 \pm 2.3$ \\
\hline \multicolumn{6}{|c|}{$\begin{array}{l}\text { a The experimental groups are identified by the type } 0 \\
\text { daily cigarettes ( } 3 \text { or } 16 \text { ) utilized for the exposures. } \\
* P<0.05 \text { vs. controls (ANOVA, } 95 \% \mathrm{CI} \text { ) }\end{array}$} \\
\hline$* * P \leq 0 .($ & VS. contr & $(\mathrm{ANOV}$ & $95 \% \mathrm{CI})$ & & \\
\hline
\end{tabular}


Table 5. Summary of the differential effects of male exposure to mainstream (MS) and sidestream (SS) tobacco smoke on motility, chromatin integrity and fertilizing capacity of mouse sperm.

\begin{tabular}{|c|c|c|c|c|}
\hline & \multicolumn{2}{|c|}{ Mainstream smoke } & \multicolumn{2}{|c|}{ Sidestream smoke } \\
\hline & $3 \mathrm{MS}$ & $16 \mathrm{MS}$ & $3 \mathrm{SS}$ & $16 \mathrm{SS}$ \\
\hline Sperm motility & & & & \\
\hline Sperm kinematics & & & & \\
\hline Sperm DNA breaks & & & & \\
\hline Sperm chromatin integrit & & & & \\
\hline Fertilization & & & & \\
\hline Embryonic development & & & & \\
\hline
\end{tabular}



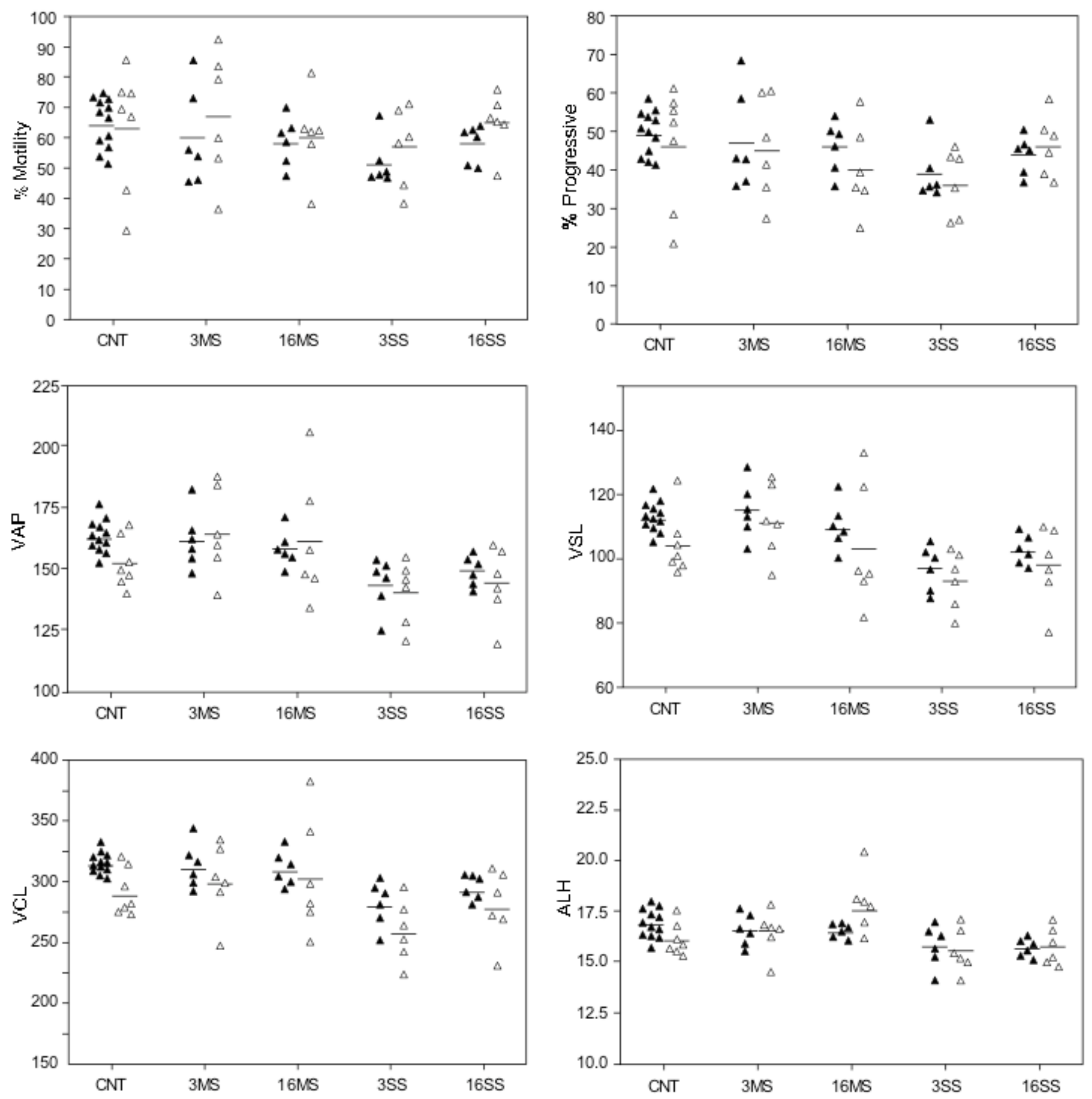

Figure 1 


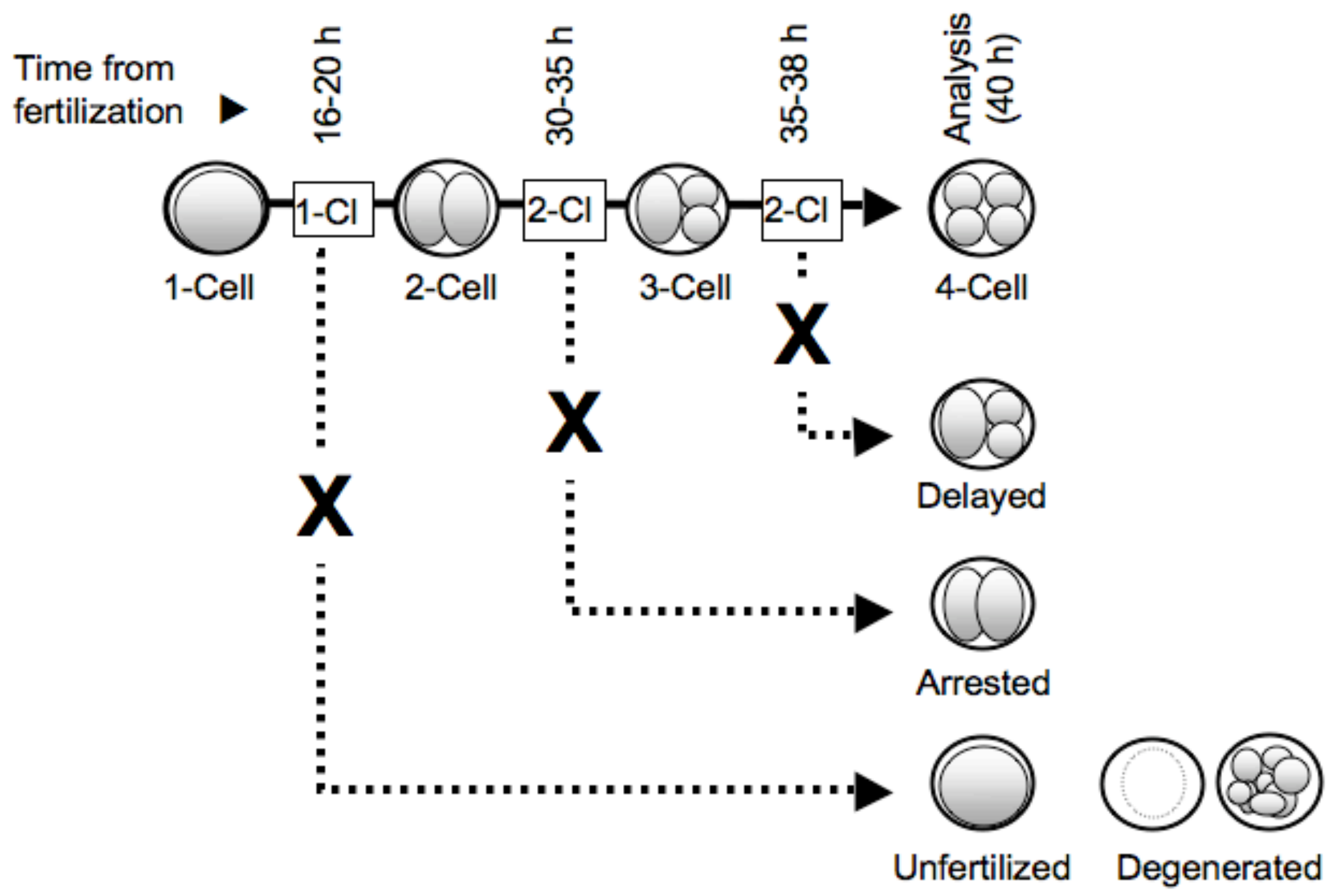

Figure 2 


\section{Supplementary Figure 1}

\section{The Mouse Smoking Machine}

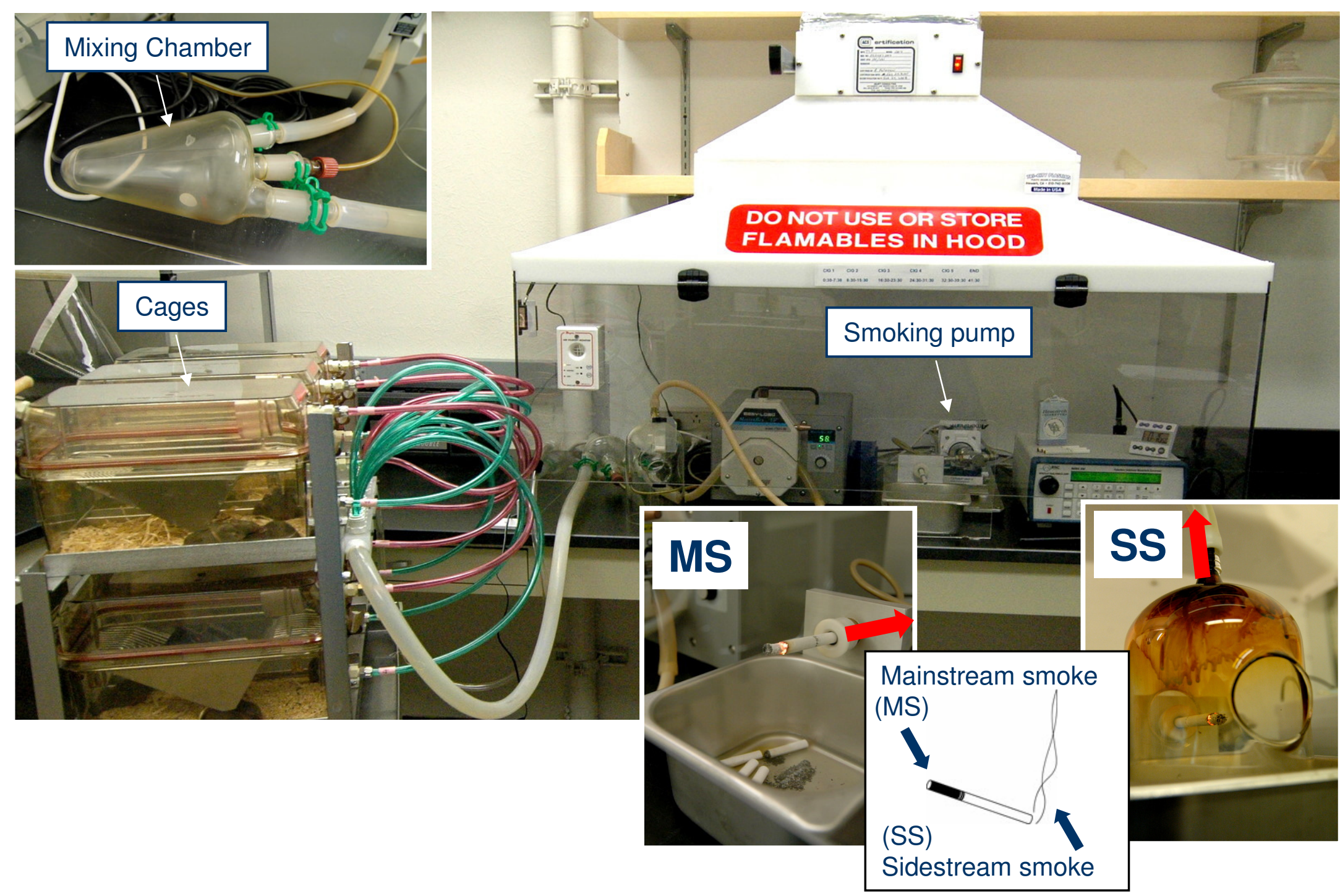




\section{SIDESTREAM (SS) SMOKE EXPOSURE}

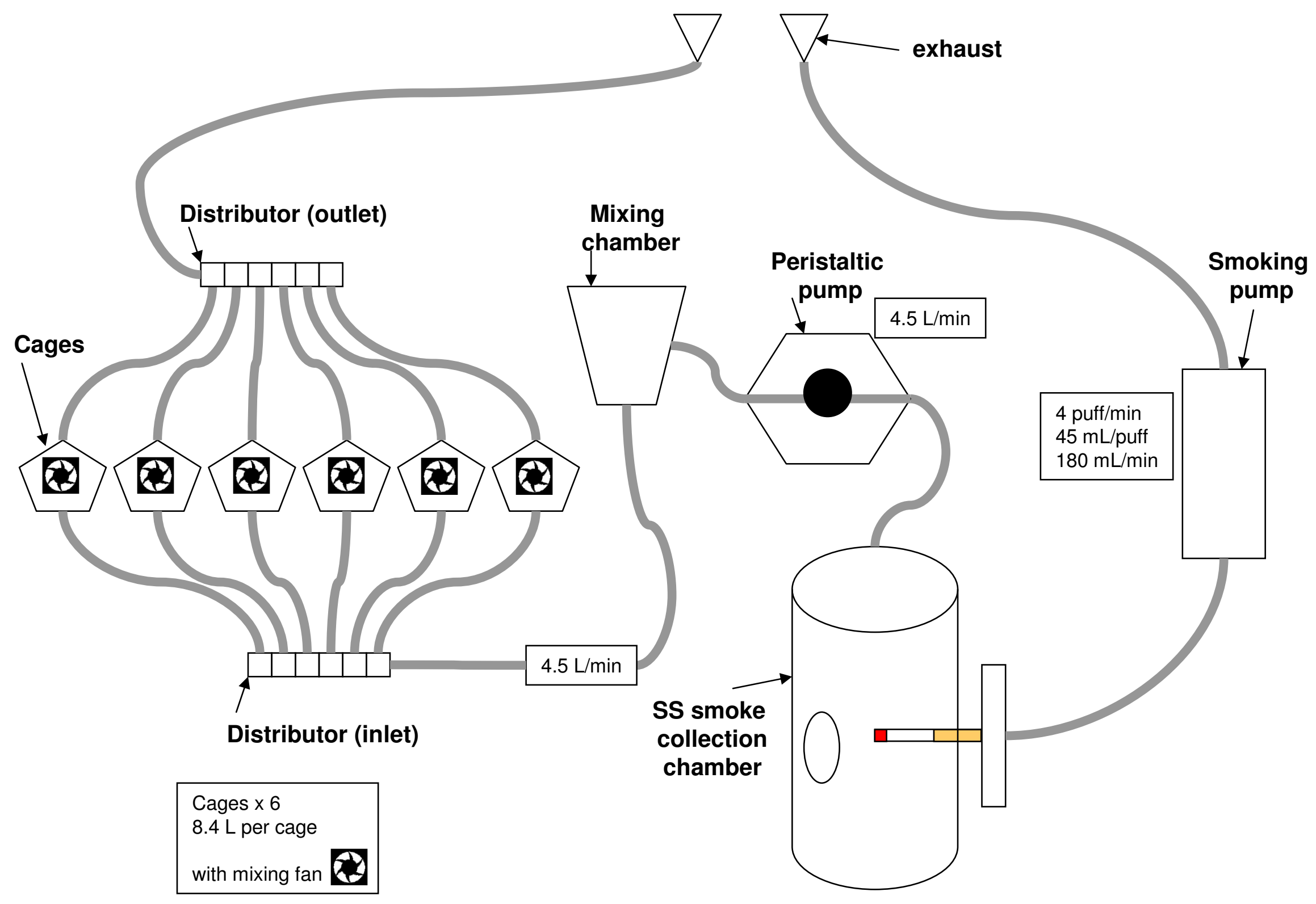

Supplementary Figure 2 


\section{MAINSTREAM (MS) SMOKE EXPOSURE}

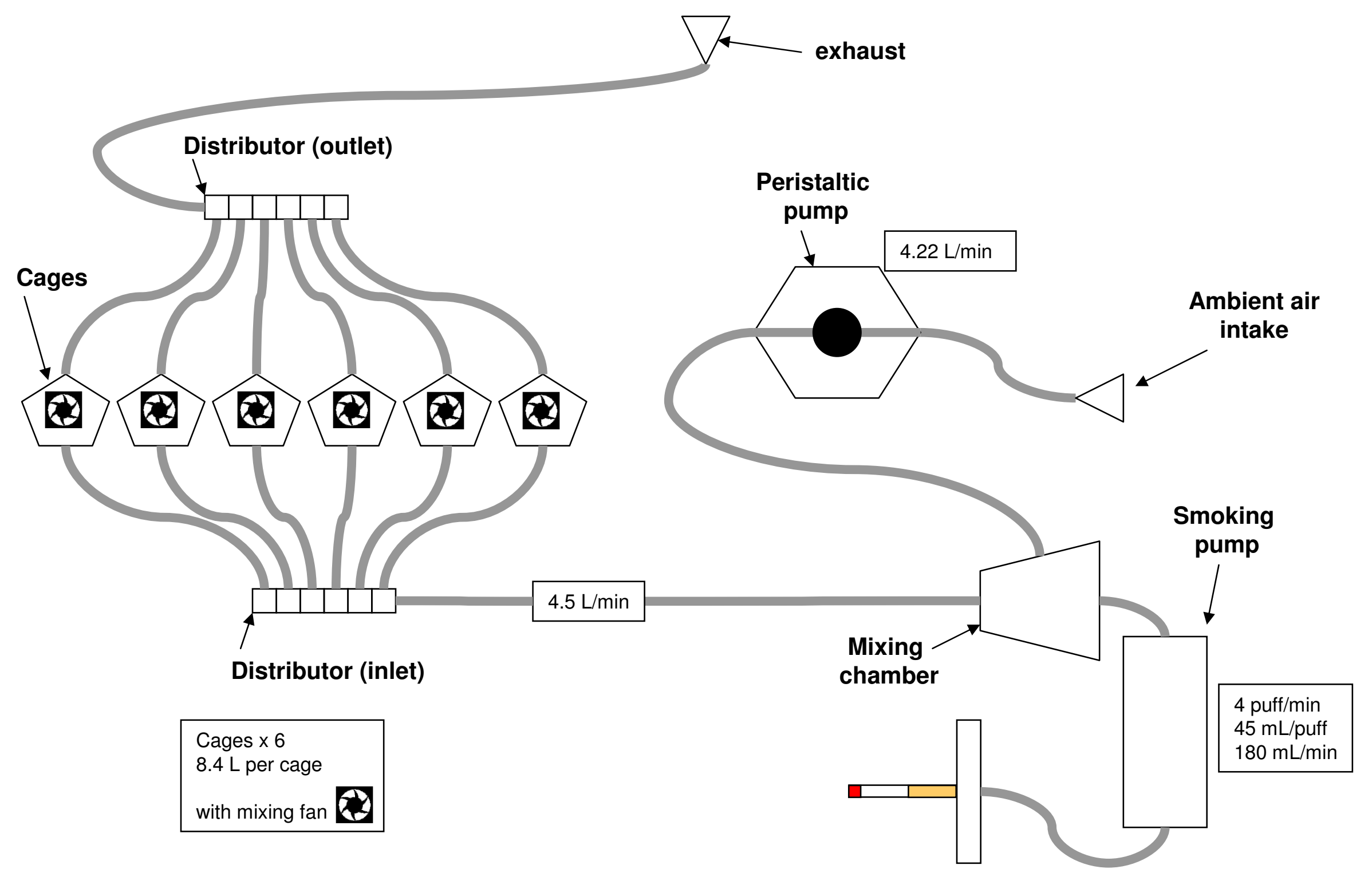

Supplementary Figure 3 